\title{
Epithelial gastric polyps
}

Polipy nabłonkowe żołądka

Department of Gastroenterology and Hepatology, Prof. K. Gibiński University Clinical Centre, Medical University of Silesia, Katowice, Poland

Correspondence: Bartosz Ostrowski, Braci Mniejszych 7B/80, 40-754 Katowice, Poland, e-mail: bartoszostrowski8@gmail.com

Abstract Gastric polyps are lesions projected above the mucosal surface, which are detected in approximately $1-6 \%$ of upper gastrointestinal endoscopies. Based to their shape, polyps are classified as pedunculate, semi-pedunculate, sessile and flat. Depending on the histopathological type, some of them have the potential to transform into adenocarcinoma. Polyps can be of epithelial and non-epithelial origin. The first group, which is discussed in greater detail in this paper, includes fundic gland polyps, hyperplastic, adenomatous and hamartomatous polyps. Non-epithelial polyps include stromal tumours, leiomyomas, fibrous inflammatory polyps, fibroids, fibromyomas, lipomas, ectopic pancreas, neuroendocrine tumours, neuromas, and some vascular lesions. Multiple polyps in patients under the age of 40 years require more extensive diagnosis for hereditary polyposis syndromes, which are associated with an increased risk of gastric cancer, as well as other gastrointestinal and extra-gastrointestinal malignancies. In recent years, there has been a clear decrease in the proportion of hyperplastic polyps and an increase in the proportion of fundic gland polyps among all gastric polyps, which is probably related to the increased use of proton pump inhibitors and a reduced incidence of Helicobacter pylori infections. About $90 \%$ of gastric polyps are detected accidentally and usually do not cause clinical symptoms, but large polyps may be responsible for anaemia, bloody stools, abdominal pain, and even pyloric obstruction, which may be manifested by vomiting, severe flatulence, lack of appetite or progressive weight loss.

Keywords: gastric polyps, gastroscopy, gastric cancer

Streszczenie Polipy żołądka to zmiany uwypuklające się ponad powierzchnię błony śluzowej, które są wykrywane w około 1-6\% endoskopii górnego odcinka przewodu pokarmowego. Ze względu na kształt polipy dzieli się na uszypułowane, półuszypułowane, przysadziste i płaskie. W zależności od typu histopatologicznego niektóre z nich cechują się potencjałem transformacji w kierunku gruczolakoraka. Polipy mogą być pochodzenia nabłonkowego i nienabłonkowego. Do pierwszej grupy, szerzej omawianej w tej pracy, należą polipy z gruczołów sklepienia żołądka, hiperplastyczne, gruczolakowate i hamartomatyczne. Z kolei do polipów nienabłonkowych zaliczają się guzy stromalne, mięśniaki gładkokomórkowe, włókniste polipy zapalne, włókniaki, włókniakomięśniaki, tłuszczaki, trzustka ektopowa, guzy neuroendokrynne, nerwiaki i niektóre zmiany naczyniopochodne. Mnogie polipy występujące u pacjentów w wieku poniżej 40. roku życia wymagają pogłębienia diagnostyki w kierunku dziedzicznych zespołów polipowatości, które wiążą się ze zwiększonym ryzykiem rozwoju raka żołądka, innych nowotworów złośliwych przewodu pokarmowego, a także nowotworów pozajelitowych. W ostatnich latach obserwuje się wyraźny spadek udziału polipów hiperplastycznych wśród wszystkich polipów żołądka i wzrost udziału polipów z gruczołów sklepienia żołądka, co jest prawdopodobnie związane ze zwiększonym stosowaniem leków z grupy inhibitorów pompy protonowej i obniżeniem częstości zakażeń Helicobacter pylori. Polipy żołądka w ponad 90\% przypadków są wykrywane przypadkowo i zazwyczaj nie powodują objawów klinicznych, lecz duże polipy mogą być odpowiedzialne za niedokrwistość, obecność krwi w stolcu, bóle brzucha, a nawet niedrożność odźwiernika, która może się manifestować wymiotami, nasilonymi wzdęciami, jadłowstrętem czy postępującą utratą masy ciała.

Słowa kluczowe: polipy żołądka, gastroskopia, rak żołądka 


\section{FUNDIC GLAND POLYPS}

$\mathrm{F}$ undic gland polyps (FGP), also known as Elster's cyst, are the most commonly diagnosed gastric polyps in developed countries. Depending on the population, they account for $16-51 \%$ of all histopathological diagnoses of benign epithelial gastric polyps (BEGP) ${ }^{(1)}$. FGPs accounted for up to $77 \%$ of polypoid lesions in a study in 120,000 patients ${ }^{(2)}$. Macroscopically, FGPs are mostly sessile with a smooth and shiny surface, usually surrounded by normal mucosa of the same colour. Single FGPs are rare; usually, there are several of them and they are small, $<1 \mathrm{~cm}$ in diameter ${ }^{(3,4)}$. They are located almost exclusively in the fundus or body of the stomach. Considering the pathogenesis of FGPs, they can be classified as sporadic, associated with long-term use of proton pump inhibitors (PPIs) and associated with familial adenomatous polyposis (FAP).

Sporadic and PPI-associated FGPs are usually detected in patients 40-70 years of age and are more common in women ${ }^{(2,4)}$. FAP-associated FGPs develop in younger individuals ( $<40$ years), are much smaller and occur with almost equal frequency in both sexes ${ }^{(4-6)}$.

Sporadic FGPs develop as a result of activating mutations of $\beta$-catenin, which is one of proteins of the APC/ $\beta$-catenin/Tcf and Wnt pathways. Although such mutations are found in cancer cells, this type of polyps contains almost no dysplastic foci ${ }^{(4,5)}$. The same mechanism generates PPI-associated polyps. Local effects of increased levels of gastrin during PPI therapy is one possible explanation of mutations ${ }^{(4,7)}$. Martin et al. showed in their meta-analysis that $15.1 \%$ of patients on PPI therapy were affected by FGPs ${ }^{(8)}$. These polyps often regress after PPI discontinuation ${ }^{(7)}$.

FAP is an autosomal dominant disorder caused by germline mutations in the $A P C$ gene. It has an incidence of approximately 1:8,000 in the general population. Patients with FAP are characterised by a significantly increased risk of colorectal cancer, as well as other malignancies, such as osteomas or foetal hepatocellular carcinoma ${ }^{(9)}$. FGPs in FAP develop as a result of $A P C$ somatic mutation. They are found in $12.5-84 \%$ of patients with FAP, which is much more often than sporadic FGPs (0.8-1.9\% of gastroscopies). Low-grade dysplasia can occur in up to $25 \%$ of FAP-associated FGP cases $^{(6)}$. Colonoscopy is needed in these patients. The risk of dysplasia and gastric cancer in non-polyposis syndrome patients with FGP is very low $(<1 \%)^{(4,10)}$.

Since FGPs have a characteristic macroscopic picture, they can be diagnosed already during endoscopy, especially when performed by an experienced endoscopist. However, specimens for histopathological examination from at least one, preferably the largest, polyp should be collected during the first endoscopic examination to confirm the diagnosis and exclude dysplasia. Polyps $>1 \mathrm{~cm}$ in diameter should be removed completely due to the increased risk of dys-
In patients on chronic PPIs who are diagnosed with large polyps $(>1 \mathrm{~cm})$, discontinuation or dose reduction, if possible, and monitoring of the size of the polyps are recommended. In the event of polyp size reduction, the same type of PPI should not be resumed, but should be switched to another PPI, at the lowest effective dose, or to agents from the class of histamine $\mathrm{H}_{2}$-receptor blockers $^{(1)}$ (Fig. 1).

\section{GASTRIC HYPERPLASTIC POLYPS}

Gastric hyperplastic polyps (GHP) are endothelial polyps arising from mucin-producing cells ${ }^{(11)}$. In their analysis of over 120,000 patients undergoing upper gastrointestinal (GI) endoscopy, Carmack et al. showed that GHPs account for $14.3 \%$ of all polyps found during gastroscopy, which makes them the second most common type of gastric polyp after FGPs ${ }^{(2)}$. They are slightly more common in women and in the elderly ${ }^{(2,12,13)}$.

GHPs are usually small, sessile, or flat, with smooth or lobular surface. Up to $72 \%$ of all GHPs have a diameter $<1 \mathrm{~cm}$, and only $4 \%$ of these polyps have a diameter $>3 \mathrm{~cm}^{(12)}$. Large polyps tend to be pedunculated with clustered or granular surface. In some cases, the mucosa that covers the GHP erodes, forming erosions that can cause chronic bleeding and iron deficiency anaemia in some patients. Narrow band imaging (NBI) endoscopy allows the visualisation of dense clusters of irregular capillaries on the surface of the polyp, which is a hallmark of GHP. Hyperplastic polyps usually develop as single lesions (68-78\%), although they can also be multiple, e.g. in Ménétrier's disease (hypertrophic gastritis) or in hyperplastic polyposis syndrome, a rare autosomal dominant disorder ${ }^{(11)}$. GHPs are located mainly in the antral part $(60 \%)$, less often in the gastric body or fundus ${ }^{(12)}$. In some cases, GHPs may be accompanied by other types of gastric polyps, most often FGPs ${ }^{(2)}$.

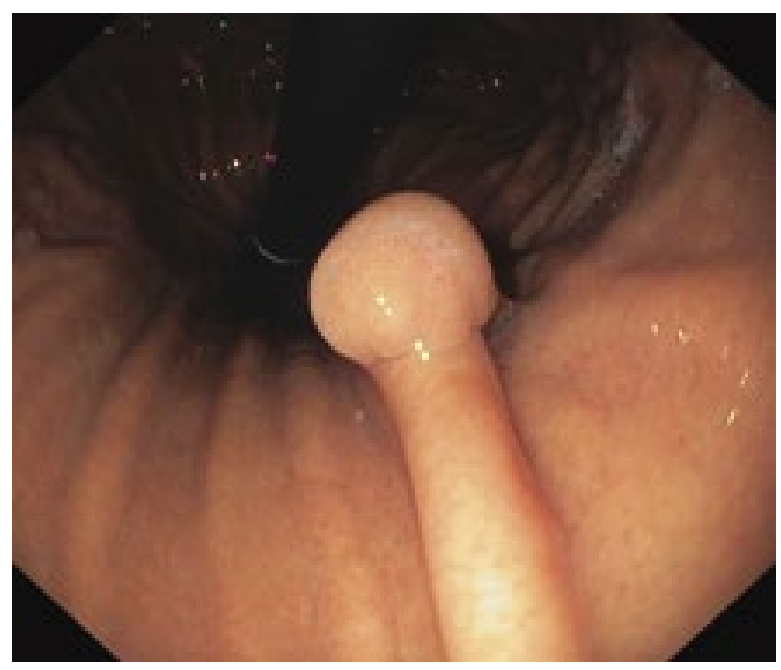

Fig. 1. Fundic gland polyp 
The cause of proliferation of mucin-producing epithelial cells remains unknown. It is presumed that the proliferation is the result of the regenerative processes of the gastric mucosa in response to damage. The main factors responsible for the development of GHPs include chronic gastritis associated with $H$. pylori infection and autoimmune metaplastic atrophic gastritis (AMAG), which can lead to Addison-Biermer anaemia. Other aetiological factors for GHPs include chemical and reactive gastropathy, dilation of the gastric antrum (the so-called watermelon stomach, gastric antral vascular ectasia, GAVE) or Zollinger-Ellison syndrome ${ }^{(12)}$. Chronic atrophic mucositis related to $H$. pylori infection, chemical or reactive gastropathy and AMAG were found in $25 \%, 21 \%$ and $12 \%$ of patients with GHP, respectively. GHPs arise from normal mucosa in only $15 \%$ of cases ${ }^{(12)}$. The involvement of repair processes in the pathogenesis of GHPs is also evidenced by the location of GHPs near gastric ulcers, erosions or a gastroenterostomy ${ }^{(11)}$.

H. pylori increases the expression of cyclooxygenase-2 (COX-2), interleukin $1 \beta$ (IL-1 $\beta$ ) and hepatocyte growth factor (HGF) in mesenchymal cells. These factors trigger local inflammatory reaction and stimulate the mitotic activity of epithelial cells, increasing cell turnover ${ }^{(14,15)}$. As a result of $H$. pylori infection, the gastric mucosa is infiltrated by macrophages, which, when activated, produce IL- $1 \beta$, which in turn activates fibroblasts and increases the expression of the mitotic factor $\mathrm{HGF}^{(15)}$. The importance of $H$. pylori infection in the pathogenesis of GHPs may be confirmed by reports on polyp size reduction or complete regression as a result of effective eradication of $H$. pylori infection, occurring in up to $80 \%$ of patients with these polyps ${ }^{(14-17)}$.

The percentage of GHPs among all polyps detected during upper GI endoscopy has changed in recent years. Studies show an increase in the number of gastric polyps with a percentage decrease in the incidence of GHPs and an increase in the incidence of FGPs ${ }^{(18-21)}$. It has been suggested that a reduction in the number of $H$. $p y$ lori infections associated with the pathogenesis of GHPs and the widespread use of PPIs, which in turn is associated with the formation of FGPs, are the cause of this phenomenon $^{(2,21)}$.

Hyperplastic polyps rarely transform into carcinomas. Research indicates that dysplasia may be present in 1.9-19\% of GHPs, although such a large range may be the result of various histopathological criteria adopted by researchers ${ }^{(3,10)}$. The incidence of adenocarcinoma ranges from 0.6 to $2.69 \%{ }^{(22,23)}$. Since GHPs arise from inflamed gastric mucosa, it is important to assess the mucosa surrounding the polyp. Abraham et al. found intestinal metaplasia in the gastric mucosa in $37 \%$, dysplasia in $2 \%$, and adenocarcinoma in $6 \%$ of GHP cases $^{(12)}$. Some studies even suggest that GHP is associated with a greater risk of dysplasia and neoplasia of the gastric mucosa than the polyp itself $^{(11,24)}$.
The size of the polyp is the most frequently mentioned risk factor for GHP neoplastic transformation. There is an increased carcinogenic risk for a polyp head $>20 \mathrm{~mm}$ in diameter ${ }^{(3)}$. For this reason, it is suggested to remove all GHPs $>5 \mathrm{~mm}$ in diameter ${ }^{(25)}$. In addition to the size of the polyp, other potential risk factors for neoplastic transformation include the presence of antibodies against the gastric parietal cells, hypergastrinemia, female sex, or $\mathrm{AMAG}^{(23)}$.

Due to the risk of dysplasia and cancer in the gastric mucosa surrounding GHPs, it is recommended to collect specimens from the gastric mucosa according to the Sydney protocol, i.e. five sections (two from the gastric antrum and body, and one from the gastric angle area ${ }^{(11)}$. The specimens should be subject to histological evaluation according to the risk stratification system for gastric cancer arising from atrophic mucositis (Operative Link for Gastritis Assessment, OLGA).

Endoscopic surveillance after polypectomy should include patients with dysplasia in the polyp (upper GI endoscopy after one year) or early gastric cancer (after one year and then after 3 consecutive years) ${ }^{(11)}$. Follow-up examinations are also recommended in patients with an increased risk of gastric cancer - OLGA III and IV (every 1-2 years) and patients who, in addition to GHPs, have dysplastic mucosa outside the polyp (every 1-3 years) ${ }^{(3,11)}$ (Fig. 2).

\section{ADENOMATOUS POLYPS}

Adenomatous polyps account for 3-26\% of all polyps, with similar rates in women and men ${ }^{(1-3)}$. Although they can be found in any gastric location, about $50 \%$ of these polyps are located in the antral part, less commonly in the angular or fundic part ${ }^{(13,26)}$. These are usually single lesions $(>80 \%)$ with lobular structure and smooth surface, soft, sessile, and different in colour than the surrounding atrophic and smooth mucosa ${ }^{(13,27)}$.

Adenomas usually arise from atrophic gastric mucositis (35\%) and intestinal metaplasia (29.6\%), which is both

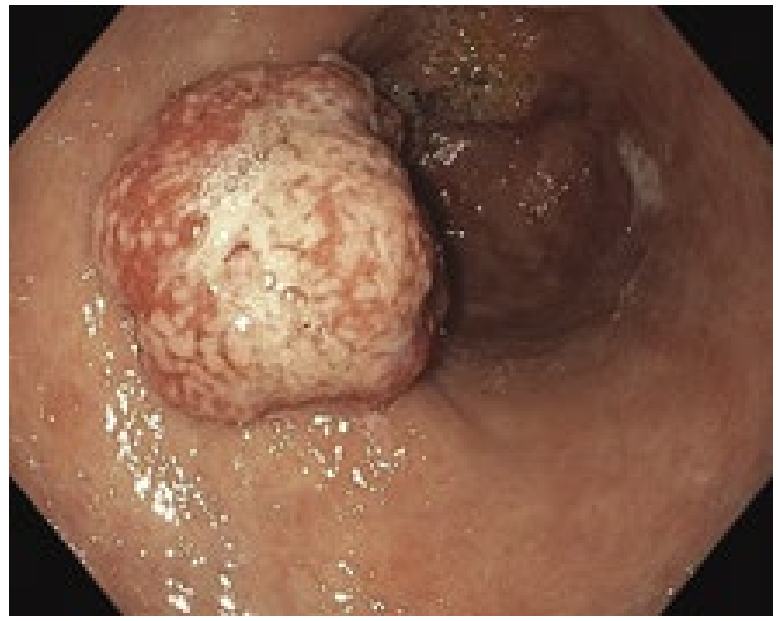

Fig. 2. Hyperplastic gastric polyp 
a precursor lesion and a high-risk factor for adenoma ${ }^{(13)}$. They are less commonly associated with $H$. pylori infection $(9.3 \%)^{(2,13)}$.

The risk of malignant transformation increases for polyps $>2 \mathrm{~cm}$ in diameter and is estimated at $28.5-40 \%$ for villous adenomatous polyps and $5 \%$ for tubular adenomatous polyps ${ }^{(1)}$. Synchronous malignancy develops in $30 \%$ of patients with adenomas $^{(3)}$. Also, an increased risk of gastric adenocarcinoma at different time points after the diagnosis of an adenomatous polyp (non-synchronous cancers) has been reported. The risk of cancer increases with age, with similar frequency in women and men ${ }^{(1,2,27)}$. The risk of cancer in the polyp is estimated at about $10 \%$ and is 5 times higher than in GHPs and two times higher than for the periGHP mucosa ${ }^{(11)}$.

Gastric adenomas usually cause no clinical symptoms except for situations when ulceration and bleeding from the polyp occur. Since adenomatous polyps are preinvasive lesions, they must be removed completely ${ }^{(13)}$. Also, the entire gastric mucosa should be investigated for lesions and if found, specimens should be collected for histopathology $\mathrm{y}^{(1,13)}$.

After polyp removal, the patient should be monitored endoscopically: endoscopic follow-up should be performed after 6 months for incompletely resected polyps or high-grade dysplasia and after a year in other cases. Eradication treatment of $H$. pylori should also be performed, and its efficacy should be confirmed ${ }^{(1)}$. There is a relationship between the presence of gastric and colorectal adenomas, therefore a colonoscopy is indicated ${ }^{(28)}$ (Fig. 3).

\section{HAMARTOMATOUS POLYPS}

Gastrointestinal hamartomatous polyps most often arise from the mucosa, although they may originate from tissues of all three germ layers. They are composed of cells and tissues found in a given organ, but they develop in a disorderly manner. These polyps are divided into sporadic polyps, which are most often single lesions and are not associated with the risk of carcinogenesis, and polyps in hereditary polyposis syndromes, such as PeutzJeghers syndrome, juvenile polyposis syndrome or Cowden syndrome.

\section{Peutz-Jeghers syndrome}

Peutz-Jeghers syndrome is an autosomal dominant disease caused by a germline mutation in the STK11/LKB1 gene, with an incidence of $1: 8,300$ to $1: 200,000^{(29,30)}$. This syndrome is associated with an increased risk of cancers, especially in the breast and the GI tract. This risk significantly increases in individuals over the age of 50 years $^{(29)}$. Dermal and mucosal pigmentation lesions located in the perianal area, on the lips, in the oral cavity and the nostrils, on the skin of fingers, hands and
Peutz-Jeghers syndrome ${ }^{(10,29)}$. The polyps are most common in the small intestine, slightly less common in the colon and the stomach, and they can also be located outside the GI system (in the urinary bladder, bronchi, gall bladder $)^{(10,29,30)}$. They have a characteristic microscopic picture, and they macroscopically resemble GHPs. They can cause overt bleeding or latent anaemia, and intussusception if located in the small bowel. As part of cancer surveillance, the first endoscopy in asymptomatic patients diagnosed with Peutz-Jeghers syndrome should be performed at the age of 8 years and repeated every 1-3 years if polyps are found. If no lesions were detected in the first examination, another gastroscopy is performed after the patient turns 18 years and is then repeated every 1-3 years. Polyps with suspicious morphology or a diameter $>1 \mathrm{~cm}$ should be removed ${ }^{(31)}$.

\section{Juvenile polyposis syndrome}

Juvenile polyposis has an incidence of $1: 100,000$ to $1: 160,000^{(30)}$. The disorder is caused by a germline BMPR1A or SMAD4 mutation and is inherited in an autosomal dominant pattern. The polyps are most commonly found in the colon, rectum, and stomach, with cancers developing in these locations. Patients with SMAD4 mutation are more likely to develop gastric polyps, gastric cancer, and have a tendency to develop hereditary haemorrhagic telangiectasia $(\mathrm{HHT})^{(30,31)}$. Single, pedunculated antral polyps, 3-20 $\mathrm{mm}$ in size are most typical and common in juvenile polyposis, although they can also be located throughout the stomach and have a diverse morphology ${ }^{(10)}$. Due to the $>50 \%$ risk of malignant transformation of the polyp, patients undergo endoscopic surveillance, and screening depends on the detected mutation ${ }^{(1)}$. For asymptomatic individuals with SMAD4 mutation, it is recommended to initiate surveillance after the age of 18 years, with endoscopic follow-up every 1-3 years, depending on the size and number of polyps. For asymptomatic patients with BMPR1A mutation, who are less likely to develop

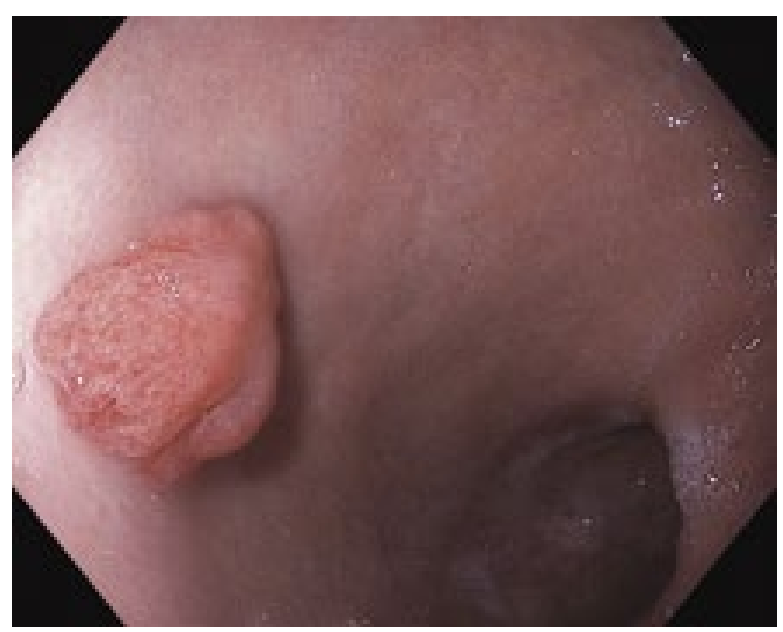

Fig. 3. Gastric adenoma 
gastric polyps, gastroscopy is performed for the first time after the age of 25 years and should also be repeated at $1-3$-year intervals ${ }^{(31)}$.

\section{Cowden syndrome}

Cowden syndrome is an autosomal dominant disorder, with a germline mutation inactivating the suppressor PTEN gene found in $80 \%$ of patients. It has an incidence of $1: 200,000$ to $1: 250,000$, is more common in women, and is usually diagnosed between 20 and 30 years of age ${ }^{(10,32)}$. The diagnosis is based on the pathognomonic clinical criteria, which include Lhermitte-Duclos disease, trichilemmoma, oral fibromas, keratosis of the hands and feet, as well as major and minor criteria. Hamartomatous polyposis of the intestine, which are included in the minor criteria, are almost always found in the rectum and the sigmoid colon and are less likely to involve the entire GI tract, including the stomach. The simultaneous presence of several histological types of polyps, with predominant hamartomatous polyps, is typical for Cowden syndrome. They differ in size, with a diameter from $1 \mathrm{~mm}$ to up to a few centimetres (most often $\leq 5 \mathrm{~mm})^{(32)}$. Macroscopically, they are similar to hyperplastic and inflammatory polyps, and therefore are sometimes misdiagnosed $^{(33)}$. Since gastric polyps in Cowden syndrome are extremely unlikely to undergo neoplastic transformation, endoscopic surveillance is not necessary. However, the disorder predisposes to other malignant neoplasms, breast, thyroid, and endometrial cancer in particular. For this reason, annual imaging and clinical examinations involving these organs are recommended from the moment the patient reaches a certain age $e^{(1,10,32)}$.

\section{CONCLUSIONS}

Gastric polyps are usually asymptomatic; hence they are detected accidentally during gastroscopy for another reason. Fundic gland polyps are most common in developed countries, while hyperplastic polyps in areas where $H$. pylori infection is still common. Hyperplastic polyps $>5 \mathrm{~mm}$ in diameter, FGPs $>10 \mathrm{~mm}$ in diameter, and all adenomas should be removed during endoscopy. FGPs may be classified as sporadic, PPI-associated and FAP-associated. These polyps pose a negligible risk of carcinogenesis. In the case of hyperplastic polyps arising from inflamed mucosa, it should be remembered that carcinogenesis may also occur in the mucosa outside the polyp; therefore it is necessary to collect a biopsy sample as well as to use eradication treatment for $H$. pylori infection if needed. Adenomatous polyps, arising from atrophic inflammation and intestinal metaplasia, are benign lesions, but with a high potential for progression to adenocarcinoma; therefore they should be completely removed with a thorough assessment of the entire gastric mucosa with a biopsy from suspicious sites. Although hamartomatous polyps developing in polyposis syndromes are rare, they should not be ignored.

\section{Conflict of interest}

The authors do not declare any financial or personal links to other persons or organisations that could adversely affect the content of this publication or claim rights thereto.

\section{References}

1. Goddard AF, Badreldin R, Pritchard DM et al.; British Society of Gastroenterology: The management of gastric polyps. Gut 2010; 59: 1270-1276.

2. Carmack SW, Genta RM, Schuler CM et al.: The current spectrum of gastric polyps: a 1-year national study of over 120,000 patients. Am J Gastroenterol 2009; 104: 1524-1532.

3. Shaib YH, Rugge M, Graham DY et al.: Management of gastric polyps: an endoscopy-based approach. Clin Gastroenterol Hepatol 2013; 11: 1374-1384.

4. Torbenson M, Lee JH, Cruz-Correa M et al.: Sporadic fundic gland polyposis: a clinical, histological, and molecular analysis. Mod Pathol 2002; 15: 718-723.

5. Abraham SC, Nobukawa B, Giardiello FM et al.: Sporadic fundic gland polyps: common gastric polyps arising through activating mutations in the beta-catenin gene. Am J Pathol 2001; 158: 1005-1010.

6. Abraham SC, Nobukawa B, Giardiello FM et al.: Fundic gland polyps in familial adenomatous polyposis: neoplasms with frequent somatic adenomatous polyposis coli gene alterations. Am J Pathol 2000; 157: 747-754.

7. Kinoshita Y, Ishimura N, Ishihara S: Advantages and disadvantages of long-term proton pump inhibitor use. J Neurogastroenterol Motil 2018; 24: 182-196.

8. Martin FC, Chenevix-Trench G, Yeomans ND: Systematic review with meta-analysis: fundic gland polyps and proton pump inhibitors. Aliment Pharmacol Ther 2016; 44: 915-925.

9. Fearnhead NS, Britton MP, Bodmer WF: The ABC of APC. Hum Mol Genet 2001; 10: 721-733.

10. Islam RS, Patel NC, Lam-Himlin D et al.: Gastric polyps: a review of clinical, endoscopic, and histopathologic features and management decisions. Gastroenterol Hepatol (N Y) 2013; 9: 640-651.

11. Markowski AR, Markowska A, Guzinska-Ustymowicz K: Pathophysiological and clinical aspects of gastric hyperplastic polyps. World J Gastroenterol 2016; 22: 8883-8891.

12. Abraham SC, Singh VK, Yardley JH et al.: Hyperplastic polyps of the stomach: associations with histologic patterns of gastritis and gastric atrophy. Am J Surg Pathol 2001; 25: 500-507.

13. Park DY, Lauwers GY: Gastric polyps: classification and management. Arch Pathol Lab Med 2008; 132: 633-640.

14. Bamba H, Ota S, Arai $\mathrm{S}$ et al.: Expression of cyclooxygenase- 2 in human hyperplastic gastric polyps. J Exp Clin Cancer Res 2003; 22: 425-430.

15. Yasunaga $Y$, Shinomura $Y$, Kanayama $S$ et al.: Increased production of interleukin 1 beta and hepatocyte growth factor may contribute to foveolar hyperplasia in enlarged fold gastritis. Gut 1996; 39: 787-794.

16. Ji F, Wang ZW, Ning JW et al.: Effect of drug treatment on hyperplastic gastric polyps infected with Helicobacter pylori: a randomized, controlled trial. World J Gastroenterol 2006; 12: 1770-1773.

17. Ohkusa T, Takashimizu I, Fujiki K et al.: Disappearance of hyperplastic polyps in the stomach after eradication of Helicobacter pylori. A randomized, clinical trial. Ann Intern Med 1998; 129: 712-715.

18. Yu X, Wang Z, Wang L et al.: Gastric hyperplastic polyps inversely associated with current Helicobacter pylori infection. Exp Ther Med 2020; 19: 3143-3149.

19. Fan NN, Yang J, Sun G et al.: Changes in the spectrum of gastric polyps in the Chinese population. World J Gastroenterol 2015; 21: 9758-9764. 
20. Velázquez-Dohorn ME, López-Durand CF, Gamboa-Domínguez A: Changing trends in gastric polyps. Rev Invest Clin 2018; 70: 40-45.

21. Cao H, Wang B, Zhang Z et al.: Distribution trends of gastric polyps: an endoscopy database analysis of 24121 northern Chinese patients. J Gastroenterol Hepatol 2012; 27: 1175-1180.

22. Terada T: Malignant transformation of foveolar hyperplastic polyp of the stomach: a histopathological study. Med Oncol 2011; 28: 941-944.

23. Hu $\mathrm{H}$, Zhang $\mathrm{Q}$, Chen $\mathrm{G}$ et al.: Risk factors and clinical correlates of neoplastic transformation in gastric hyperplastic polyps in Chinese patients. Sci Rep 2020; 10: 2582.

24. Orlowska J, Jarosz D, Pachlewski J et al.: Malignant transformation of benign epithelial gastric polyps. Am J Gastroenterol 1995; 90: 2152-2159.

25. Ginsberg GG, Al-Kawas FH, Fleischer DE et al.: Gastric polyps: relationship of size and histology to cancer risk. Am J Gastroenterol 1996; 91: 714-717.

26. Morais DJ, Yamanaka A, Zeitune JM et al.: Gastric polyps: a retrospective analysis of 26,000 digestive endoscopies. Arq Gastroenterol 2007; 44: 14-17.
27. Hattori T: Morphological range of hyperplastic polyps and carcinomas arising in hyperplastic polyps of the stomach. J Clin Pathol 1985; 38: 622-630.

28. Yang MH, Son HJ, Lee JH et al.: Do we need colonoscopy in patients with gastric adenomas? The risk of colorectal adenoma in patients with gastric adenomas. Gastrointest Endosc 2010; 71: 774-781.

29. Beggs AD, Latchford AR, Vasen HF et al.: Peutz-Jeghers syndrome: a systematic review and recommendations for management. Gut 2010; 59: 975-986.

30. Jelsig AM, Qvist N, Brusgaard K et al.: Hamartomatous polyposis syndromes: a review. Orphanet J Rare Dis 2014; 9: 101.

31. van Leerdam ME, Roos VH, van Hooft JE et al.: Endoscopic management of polyposis syndromes: European Society of Gastrointestinal Endoscopy (ESGE) Guideline. Endoscopy 2019; 51: 877-895.

32. Farooq A, Walker LJ, Bowling J et al.: Cowden syndrome. Cancer Treat Rev 2010; 36: 577-583.

33. Shaco-Levy R, Jasperson KW, Martin K et al.: Morphologic characterization of hamartomatous gastrointestinal polyps in Cowden syndrome, Peutz-Jeghers syndrome, and juvenile polyposis syndrome. Hum Pathol 2016; 49: 39-48. 